\title{
Differential response of UCP3 to medium versus long chain triacylglycerols; manifestation of a functional adaptation
}

Citation for published version (APA):

Hoeks, J., Hesselink, M. K. C., van Bilsen, M., Schaart, G., van der Vusse, G. J., Saris, W. H. M., \& Schrauwen, P. (2003). Differential response of UCP3 to medium versus long chain triacylglycerols; manifestation of a functional adaptation. Febs Letters, 555(3), 631-637. https://doi.org/10.1016/S00145793(03)01343-7

Document status and date:

Published: 01/01/2003

DOI:

10.1016/S0014-5793(03)01343-7

Document Version:

Publisher's PDF, also known as Version of record

Please check the document version of this publication:

- A submitted manuscript is the version of the article upon submission and before peer-review. There can be important differences between the submitted version and the official published version of record.

People interested in the research are advised to contact the author for the final version of the publication, or visit the DOI to the publisher's website.

- The final author version and the galley proof are versions of the publication after peer review.

- The final published version features the final layout of the paper including the volume, issue and page numbers.

Link to publication

\footnotetext{
General rights rights.

- You may freely distribute the URL identifying the publication in the public portal. please follow below link for the End User Agreement:

www.umlib.nl/taverne-license

Take down policy

If you believe that this document breaches copyright please contact us at:

repository@maastrichtuniversity.nl

providing details and we will investigate your claim.
}

Copyright and moral rights for the publications made accessible in the public portal are retained by the authors and/or other copyright owners and it is a condition of accessing publications that users recognise and abide by the legal requirements associated with these

- Users may download and print one copy of any publication from the public portal for the purpose of private study or research.

- You may not further distribute the material or use it for any profit-making activity or commercial gain

If the publication is distributed under the terms of Article 25fa of the Dutch Copyright Act, indicated by the "Taverne" license above, 


\title{
Differential response of UCP3 to medium versus long chain triacylglycerols; manifestation of a functional adaptation
}

\author{
Joris Hoeks ${ }^{\mathrm{a}, *}$, Matthijs K.C. Hesselink ${ }^{\mathrm{b}}$, Marc van Bilsen ${ }^{\mathrm{c}}$, Gert Schaart $^{\mathrm{b}}$, \\ Ger J. van der Vusse ${ }^{\mathrm{c}}$, Wim H.M. Saris ${ }^{\mathrm{a}}$, Patrick Schrauwen ${ }^{\mathrm{a}}$ \\ ${ }^{a}$ Department of Human Biology, Nutrition and Toxicology Research Institute Maastricht (NUTRIM), Maastricht University, P.O. Box 616, \\ 6200 MD Maastricht, The Netherlands \\ ${ }^{\mathrm{b}}$ Department of Movement Sciences, Nutrition and Toxicology Research Institute Maastricht (NUTRIM), Maastricht University, Maastricht \\ The Netherlands \\ ${ }^{\mathrm{c}}$ Department of Physiology, Cardiovascular Research Institute Maastricht (CARIM), Maastricht University, Maastricht, The Netherlands
}

Received 10 September 2003; revised 6 November 2003; accepted 10 November 2003

First published online 24 November 2003

Edited by Guido Tettamanti

\begin{abstract}
We compared UCP3 protein in rat cardiac, glycolytic and oxidative skeletal muscle and examined the effect of high-fat medium chain vs. long chain triacylglycerol feeding on UCP3 content in these tissues. Cardiac muscle displays the lowest basal levels of UCP3 protein. Increasing long chain - but not medium chain - fatty acid supply upregulates UCP3 in all muscles. Since plasma non-esterified fatty acids and the expression of two peroxisome proliferator-activated receptor (PPAR)responsive genes, were not different between groups, we conclude that the differential upregulation of UCP3 is not merely PPAR-mediated. This study supports a role of UCP3 in export of non-metabolizable fatty acids.

(C) 2003 Federation of European Biochemical Societies. Published by Elsevier B.V. All rights reserved.
\end{abstract}

Key words: UCP3; Thermogenesis;

Medium chain triacylglycerol; Mitochondrion; High-fat diet; Peroxisome proliferator-activated receptor; Lipotoxicity

\section{Introduction}

The function of UCP3 is still under debate but there is increasing evidence that the primary physiological role of UCP3 is in fatty acid metabolism. Evaluation of the available data on UCP3 expression shows that skeletal muscle UCP3 is upregulated in situations where fatty acid supply exceeds fat oxidative capacity such as acute fasting [1], high-fat diet [2-4] and acute exercise [5]. On the other hand UCP3 is downregulated in situations where fat oxidation capacity is improved like endurance training [6,7] or during weight reduction $[8,9]$. In conditions where fatty acid supply exceeds fat oxidation capacity, non-esterified fatty acids will accumulate in the cytosol and might enter the mitochondrial matrix through flipflop [6,10-12]. Based on these findings, we and others hypothesized that the physiological function of UCP3 is to protect mitochondria from accumulation of non-esterified fatty acids inside the mitochondrial matrix, especially in situations where fatty acid delivery exceeds oxidation capacity $[6,12,13]$.

In accordance with this hypothesis it was found that skeletal muscle with the lowest fat oxidative capacity (glycolytic,

*Corresponding author. Fax: (31)-43-3670976.

E-mail address: j.hoeks@hb.unimaas.nl (J. Hoeks). type $2 \mathrm{~b}$ muscle fibers) display the highest UCP3 mRNA and protein levels while oxidative muscles (type 1 muscle fibers) only moderately express UCP3 $[14,15]$. In this context, it is interesting to note that cardiac muscle (CM), which mainly depends on fatty acids for its energy supply, also expresses UCP3 mRNA [16,17] and protein [16], while the level of UCP3 protein relative to skeletal muscle is unknown. As $\mathrm{CM}$ has a very high capacity to oxidize fatty acids, we hypothesize that it contains UCP3 at levels even lower than in type 1 muscle fibers. Therefore, the first aim of the present study was to determine UCP3 protein levels in rat $\mathrm{CM}$ and to compare these levels with UCP3 levels in the white gastrocnemius (WGM; mainly glycolytic) and soleus (SM; mainly oxidative) muscle.

Additional support for a role for UCP3 in fat metabolism comes from the finding that prolonged consumption of a high-fat diet upregulates skeletal muscle UCP3 mRNA and protein levels, both in humans [2,4] and rodents [3,18]. During high-fat feeding, fatty acid supply exceeds the oxidative capacity and fatty acids are likely to accumulate in the cytosol. As a result, the entry of non-esterified fatty acids into the mitochondrial matrix most likely increases and the observed upregulation of UCP3 may facilitate outward transport of these non-metabolizable fatty acids. Therefore, it is of relevance to study the effect of high-fat feeding on UCP3, at the protein level, in muscles with different fat oxidative capacities.

We recently showed that the upregulation of UCP3 in WGM upon high-fat feeding in rats is specific for long chain triacylglycerols (LCT) and completely absent when equal amounts of medium chain triacylglycerols (MCT) are provided [19]. Because of their chain-length, medium chain fatty acids (MCFA), in contrast to long chain fatty acids (LCFA), do not rely on the carnitine shuttle system for their transport across the mitochondrial membranes. In addition, they can be readily oxidized inside the matrix because of the presence of a matrix-associated enzyme which allows the activation and subsequent $\beta$-oxidation of MCFA [20]. Therefore, upregulation of UCP3 upon high-fat MCT feeding would be redundant since non-esterified MCFA that enter the mitochondrial matrix can still be oxidized. Here, we extend our previous finding [19] and examine the effect of high-fat, MCT vs. LCT feeding on UCP3 protein content in the three earlier mentioned muscles with different oxidative capacity. In addition, we examined whether the lack of effect of MCT on 
UCP3 could be due to differential peroxisome proliferatoractivated receptor (PPAR)-induced UCP3 gene regulation. The promoter of UCP3 contains a PPAR-responsive element [21], and LCFA are identified activators of PPARs while MCFA activate PPARs to a much lesser extent [22,23]. Hence, it could be argued that the lack of upregulation of UCP3 on a diet comprised of mainly MCTs merely reflects the lack of PPAR responsiveness to MCTs rather than a functional adaptation of $\mathrm{UCP} 3$ to the increased mitochondrial LCFA supply.

Therefore, the final aim was to study the gene expression of UCP3 as well as two other, well-established, PPAR-responsive genes, acyl-CoA synthetase (ACS) and long chain acyl-CoA dehydrogenase (LCAD), upon high-fat MCT or LCT feeding.

\section{Material and methods}

\subsection{Animals}

Thirty male, 10 week old Wistar rats (Charles River) were housed individually on a $12: 12 \mathrm{~h}$ light-dark cycle (light from $7.00 \mathrm{~h}$ to $19.00 \mathrm{~h}$ ), at $21-22^{\circ} \mathrm{C}$ and subjected to a 2 week dietary intervention. During the experiments, rats had free access to tap water. All experiments were approved by the Institutional Animal Care and Use Committee of the Maastricht University and complied with the principles of laboratory animal care.

\subsection{Diets}

Rats were randomly divided into three different groups $(n=10)$ Group 1 (LF LCT) received the low-fat control diet ( 7 net energy $(\mathrm{EN}) \%$ from fat) for the duration of 2 weeks. Group 2 (HF MCT) was maintained on a high-fat MCT diet while group 3 (HF LCT) received a high-fat LCT diet (both $46 \mathrm{EN} \%$ from fat). Diet specifications are displayed in Table 1. All diets were purchased from Hope Farms (Woerden, The Netherlands) and provided ad libitum. Food intake and body mass were recorded daily.

To check net energy intake in the high-fat groups, diet and fecal samples were analyzed for gross energy content using adiabatic bomb calorimetry. Basal differences in UCP3 protein concentrations between WGM, SM and CM were compared in four rats of the lowfat control group.

\subsection{Tissue sampling}

After the 2 week dietary intervention period, tissue dissection was performed under ketamine $\left(\mathrm{Nimatek}^{\circledR} 1.0 \mathrm{ml} / \mathrm{kg}\right.$ ) and xylazine (Sedamun ${ }^{\circledR} 0.5 \mathrm{ml} / \mathrm{kg}$ ) anesthesia upon short-term (less than $20 \mathrm{~s}$ ) $\mathrm{CO}_{2}$ sedation. Both anesthetics were injected subcutaneously. Rats were deprived from food approximately $6 \mathrm{~h}$ prior to tissue sampling. $\mathrm{CM}$ and the mid-belly regions of the WGM and SM were dissected and immediately frozen in liquid nitrogen. Furthermore, a blood sample was collected in EDTA-containing Eppendorf tubes and plasma was prepared by centrifugation at $10000 \times g$ for $2 \mathrm{~min}$. Plasma samples were also frozen in liquid nitrogen. All samples were stored at $-80^{\circ} \mathrm{C}$ until analysis.

\subsection{Non-esterified fatty acids}

Plasma samples were analyzed for total non-esterified fatty acids using the Wako NEFA C test kit (Wako Chemicals, Neuss, Germany).

\subsection{Analysis of $m R N A$ expression}

Northern blot analysis of mRNA was performed as described elsewhere [24]. Specifically, filters were probed with a $0.7 \mathrm{~kb}$ fragment of rat UCP3 generated via reverse transcriptase PCR using forward (5'GGCCATCCTCCGGAACCATGG-3') and reversed (5'-GCGGCCTGCTTGCCTTGTTCA-3') primers, a 520 bp EcoRV-HindIII fragment of ACS (gift from Dr. T. Yamamoto, Tohoku University, Sendai, Japan), and a 1390 bp EcoRI fragment of rat LCAD (a gift from Dr. K. Tanaka, Yale University, USA).

\subsection{UCP3 protein content}

Western blot analysis of UCP3 protein was performed as described elsewhere [19]. The affinity purified polyclonal antiserum against rUCP3 (code 1338, kindly provided by L.J. Slieker, Eli Lilly) was raised in a rabbit against a 20 amino acid peptide that comprised amino acids $147-166$ of rat UCP3 (rUCP3). The purified antiserum was tested extensively for specificity in immunoblotting assays using positive and negative controls (i.e. brown adipose tissue, skeletal muscle and UCP3 knock-out mice). Since the rUCP3 antiserum shows cross reactivity with human tissues, the reactivity and specificity of this antiserum was compared with the hUCP3 polyclonal antiserum [15], both resulting in a UCP3 product of $33 \mathrm{kDa}$ in human skeletal muscle. After pre-incubation of the antibody with the peptide, the specific $33 \mathrm{kDa}$ UCP3 protein band was absent.

\subsection{Statistical analysis}

Results are presented as mean \pm S.E.M. UCP3 levels upon control feeding were set at 100 arbitrary units. Differences between groups were evaluated by analysis of variance (one-way ANOVA). When significant differences were found, a Bonferroni adjusted post-hoc test was used to determine the exact location of the difference. Outcomes were regarded as statistically significant if $P<0.05$.

\section{Results}

\subsection{Gain of body mass and energy intake}

By the end of the 2 week dietary intervention period, the gain of body mass in the HF LCT group was $53.0 \pm 1.5 \mathrm{~g} / 2$ weeks, which was significantly higher than in the LF LCT $(45.3 \pm 1.0 \mathrm{~g} / 2$ weeks; $P=0.034)$ and HF MCT $(44.6 \pm 2.9$ $\mathrm{g} / 2$ weeks; $P=0.018$ ) groups (Table 2 ). Gross energy intake over the 2 week period was also significantly higher in the HF LCT group (5727 $\pm 116 \mathrm{~kJ} / 2$ weeks) compared to the LF LCT $(4824 \pm 88 \mathrm{~kJ} / 2$ weeks; $P<0.001)$ and HF MCT $(4434 \pm 124$ $\mathrm{kJ} / 2$ weeks; $P<0.001$ ) groups (Table 2 ). There was a trend $(P=0.06)$ towards a higher gross energy intake in the LF LCT group in comparison with the HF MCT group. However,

Table 1

Major components and fatty acid composition of triacylglycerols in experimental diets

\begin{tabular}{llll}
\hline Diet & Group 1: LF control & Group 2: HF MCT & Group 3: HF LCT \\
\hline Protein (EN\%) & 19 & 19 & 19 \\
Carbohydrates (EN\%) & 74 & 35 & 35 \\
Fat (EN\%) & 7 & 46 & 46 \\
\hline Fatty acid profile & $\%$ of total fat & $\%$ of total fat & of total fat \\
\hline C8:0 & 0.5 & 60.0 & 0.5 \\
C10:0 & 1.0 & 40.0 & 79.0 \\
C14:0 & 79.0 & & 6.0 \\
C18:0 & 6.0 & & 12.0 \\
C18:1 & 12.0 & & 1.0
\end{tabular}

Minerals and vitamins were added in order to provide $100 \%$ of AIN requirements for rats. 
Table 2

Gain of body mass and energy intake over 2 weeks of dietary intervention

\begin{tabular}{llll}
\hline Parameter & LF LCT & HF MCT & HF LCT \\
\hline Gain of body mass $(\mathrm{g})$ & $45.3 \pm 1.0$ & $44.6 \pm 2.9$ & $53.0 \pm 1.5^{* \dagger}$ \\
Gross energy intake $(\mathrm{kJ})$ & $4824 \pm 88$ & $4434 \pm 124$ & $5727 \pm 116^{* * \dagger \dagger}$ \\
Net energy intake $(\mathrm{kJ})$ & - & $3956 \pm 116$ & $4214 \pm 87$ \\
Energy intake per gram gain of body mass $(\mathrm{kJ} / \mathrm{g})$ & - & $91 \pm 4$ & $80 \pm 2^{\dagger}$ \\
\hline
\end{tabular}

Values are means \pm S.E.M. ${ }^{*} P<0.05,{ }^{* *} P<0.001$ compared to LF LCT, ${ }^{\dagger} P<0.05,{ }^{\dagger \dagger} P<0.001$ compared to HF MCT.

adiabatic bomb calorimetry of the fecal samples of both highfat groups revealed that the amount of energy lost in the feces was significantly higher in the HF LCT group compared to the HF MCT group $(1514 \pm 45$ vs. $477 \pm 23 \mathrm{~kJ} / 2$ weeks; $P<0.001)$ As a result, net energy intake in the HF LCT group was not different from the HF MCT group over the 2 week intervention period ( $4214 \pm 87$ vs. $3956 \pm 116 \mathrm{~kJ}$; NS). Therefore, the net energy intake per gram gain of body mass was significantly higher in the HF MCT group $(90.8 \pm 4.1$ $\mathrm{kJ} / \mathrm{g})$ than in the HF LCT group $(79.9 \pm 1.6 \mathrm{~kJ} / \mathrm{g} ; P=0.024$, Table 2), indicating that energy expenditure was increased on the HF MCT diet.

\subsection{Plasma free fatty acids}

After 2 weeks of dietary intervention, plasma non-esterified fatty acid levels averaged $201 \pm 20 \mu \mathrm{mol} / 1$ in the LF LCT group, while the HF MCT and HF LCT plasma non-esterified fatty acid levels averaged $249 \pm 34$ and $274 \pm 26 \mu \mathrm{mol} / 1 \mathrm{respec}-$ tively. These differences did not reach statistical significance.

\subsection{UCP3 protein content}

Basal UCP3 protein levels in WGM were approximately 4.5-fold higher than the SM and $\sim 13$-fold higher compared to $\mathrm{CM}(550 \pm 102$ vs. $118 \pm 42$ and $42 \pm 17$ arbitrary units, in WGM vs. SM and CM respectively, $P<0.005$ ). Thus, CM displayed the lowest UCP3 protein levels, which were 2.8fold lower than SM UCP3 protein levels (118 \pm 42 vs. $42 \pm 17$ arbitrary units), although the latter difference failed to reach statistical significance (Fig. 1).

High-fat LCT feeding significantly increased UCP3 protein content in WGM by 2 -fold in comparison with the low-fat diet $(201 \pm 36$ vs. $100 \pm 22$ arbitrary units, $P<0.05)$, while
MCT feeding did not affect UCP3 protein levels (86 \pm 17 vs. $100 \pm 21$ arbitrary units, NS; Fig. 2A).

UCP3 protein content in SM (Fig. 2B) increased 4.5-fold upon HF LCT feeding compared to the control diet $(451 \pm 81$ vs. $100 \pm 46$ arbitrary units, $P<0.005$ ). Again, there was no difference in UCP3 protein levels in SM between HF MCT feeding and the low-fat control diet $(168 \pm 58$ vs. $100 \pm 46$, NS).

CM UCP3 protein content (Fig. 2C) showed an 11.5-fold increase after the HF LCT diet intervention (1150 \pm 211 vs. $100 \pm 17$ arbitrary units, $P<0.001)$. HF MCT showed a tendency towards an increase in UCP3 protein levels in CM but, due to high variation, this increase was not statistically significant $(578 \pm 67$ vs. $100 \pm 17$, NS).

Although the high-fat-induced increase in UCP3 is most pronounced in $\mathrm{CM}$, it should be kept in mind that the baseline levels were 13-fold lower in CM compared to WGM. If the basal differences were taken into account, absolute UCP3 values after 2 weeks of HF LCT feeding would still be highest in WGM compared to SM and CM.

\section{4. $m R N A$ analysis}

After 2 weeks of dietary intervention UCP3 mRNA levels mimicked the change in protein levels in CM and WGM. Thus, UCP3 mRNA levels in the WGM increased by $\sim 75 \%$ upon HF LCT feeding compared to the control diet although this difference did not reach statistically significance (176 \pm 40 vs. $100 \pm 18$ arbitrary units, NS). UCP3 mRNA levels after HF MCT feeding were comparable to control values $(131 \pm 35$ vs. $100 \pm 18$ arbitrary units; Fig. 3B).

In CM, UCP3 mRNA levels increased 11-fold upon HF LCT feeding compared to the low-fat control diet $(1121 \pm$

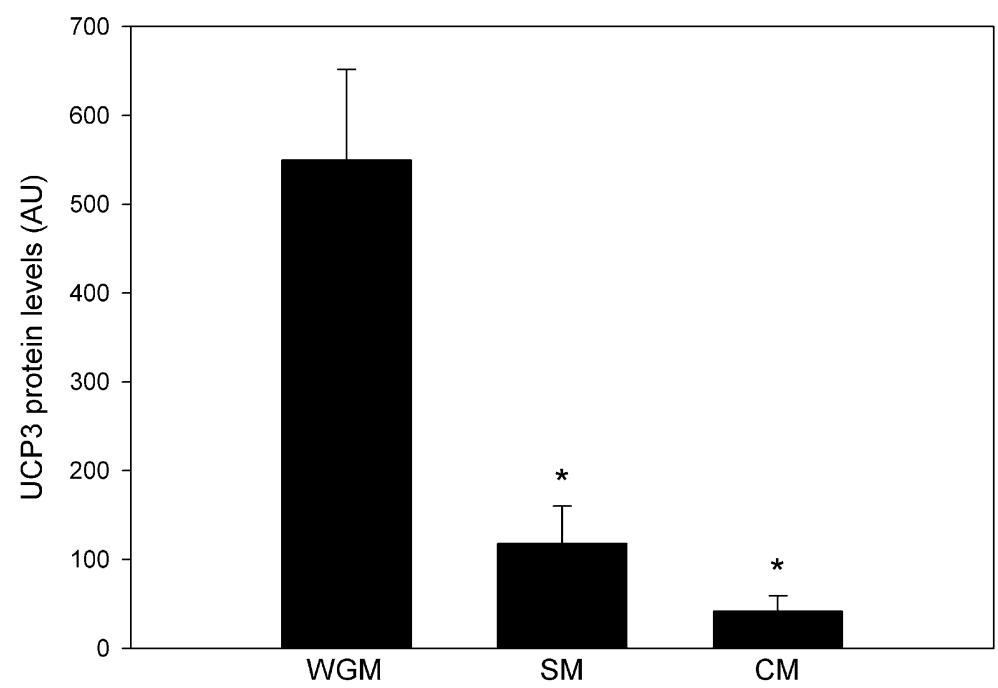

Fig. 1. Basal UCP3 protein levels among different muscles. Values are mean \pm S.E.M. ${ }^{*} P<0.005$ compared to WGM (SM: soleus muscle). 

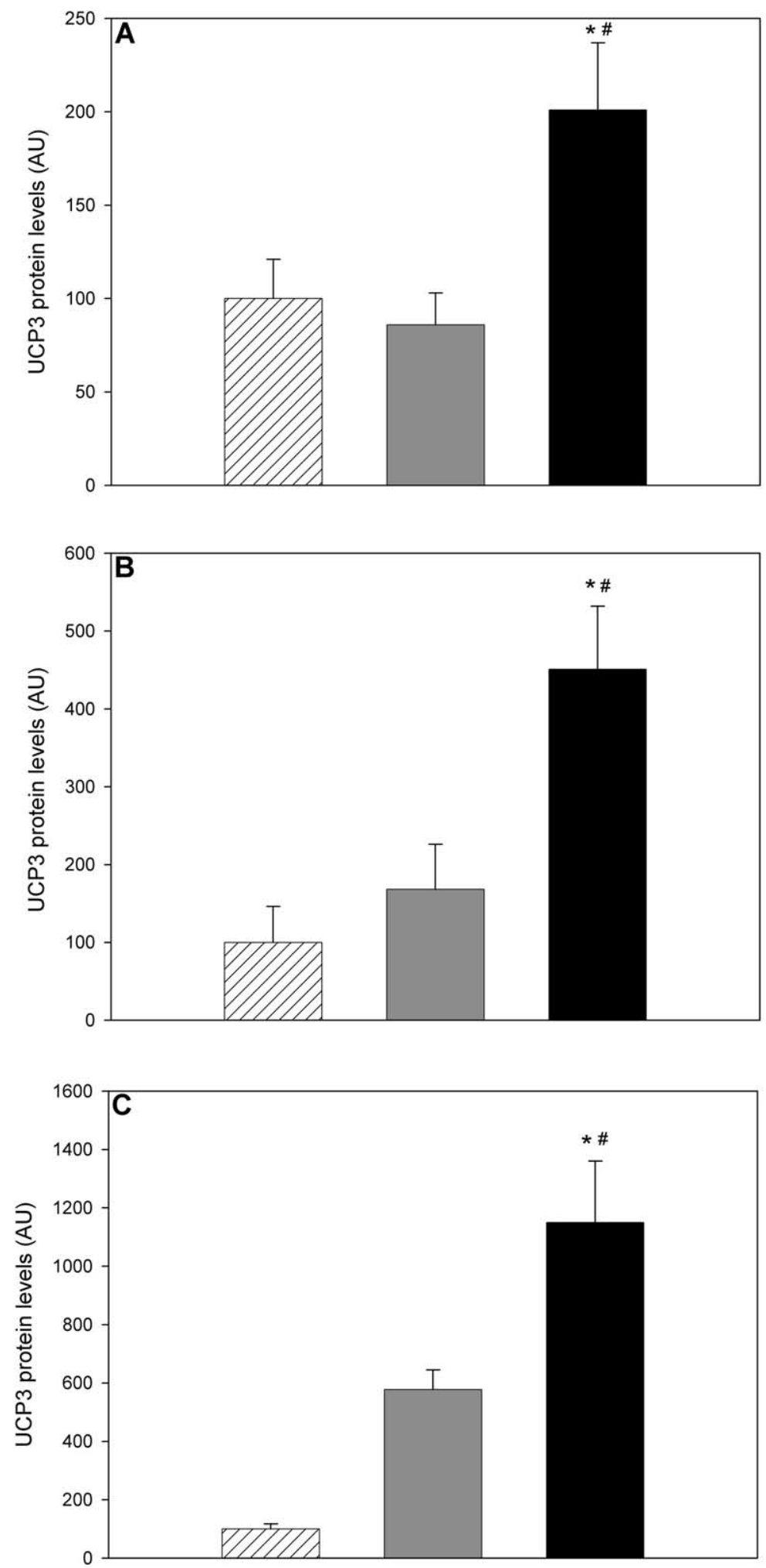

Fig. 2. UCP3 protein levels. Protein levels of UCP3 after dietary intervention in (A) WGM, (B) SM and (C) CM. Values are mean \pm S.E.M. $* P<0.05$ compared to LF LCT. ${ }^{\#} P<0.05$ compared to HF MCT (striped boxes: LF LCT; gray boxes: HF MCT; black boxes: HF LCT).

378 vs. $100 \pm 18$ arbitrary units, $P<0.001)$ whereas after $\mathrm{HF}$ MCT feeding UCP3 mRNA expression in rat heart were not significantly different from control values $(333 \pm 137$ vs. $100 \pm 18$ arbitrary units, NS; Fig. 3A).
In contrast, gene expression of the well-established PPAR responsive genes, ACS and LCAD, did not respond to either the high-fat LCT or MCT feeding, neither in CM nor in skeletal muscle (Fig. 3). 

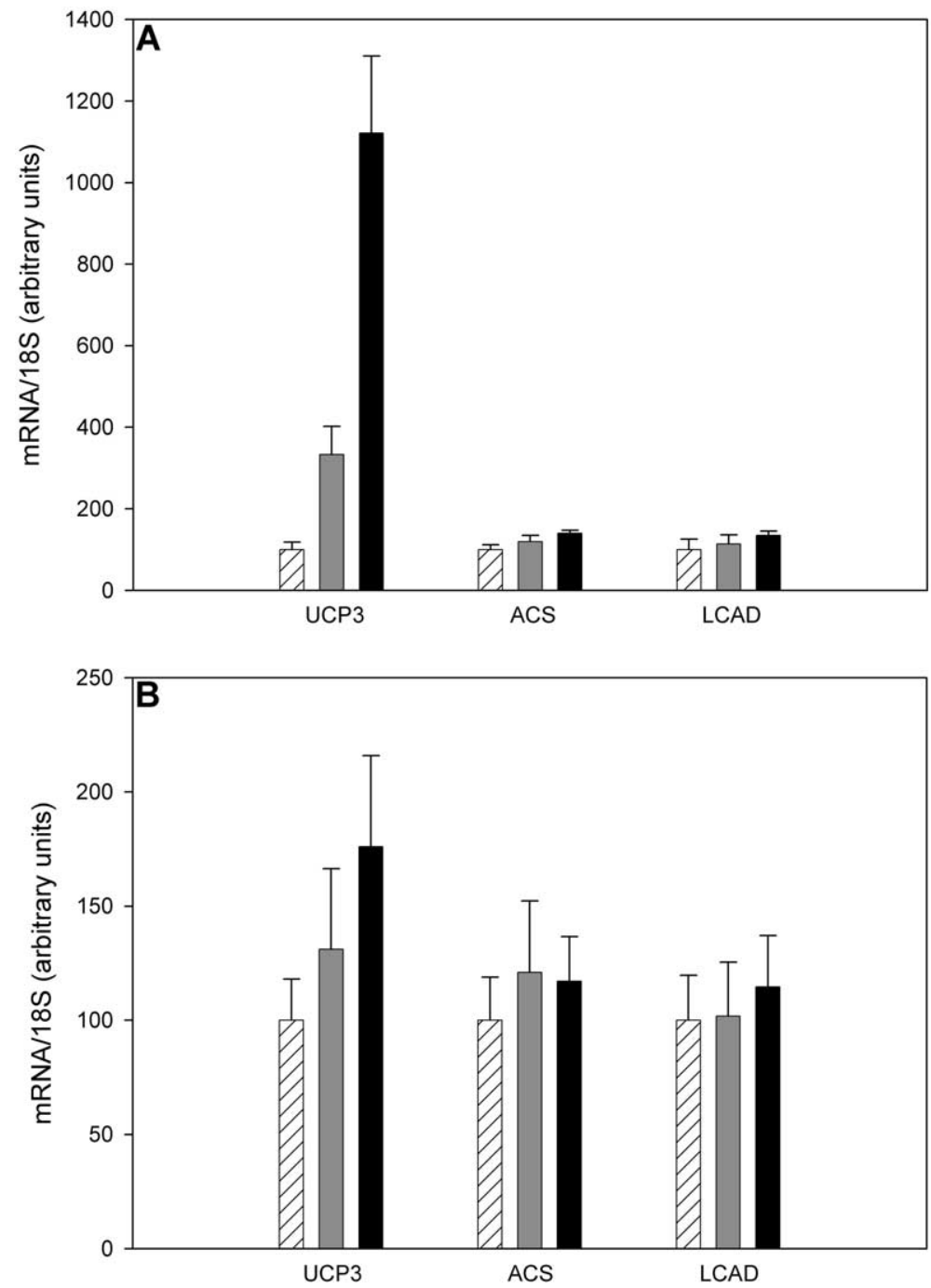

Fig. 3. mRNA in muscle tissue. Expression of UCP3, ACS and LCAD after dietary intervention in (A) CM and (B) WGM. Values are mean \pm S.E.M. (striped boxes: LF LCT; gray boxes: HF MCT; black boxes: HF LCT).

\section{Discussion}

We previously hypothesized that UCP3 acts as a fatty acid anion exporter, hence preventing accumulation of non-metabolizable fatty acid anions inside the mitochondrial matrix [6]. Such a function of UCP3 is of importance, as fatty acid anions are prone to lipid peroxidation and could potentially damage mitochondrial DNA and proteins. According to this hypothesis, UCP3 is especially needed in muscle with low-fat oxidative capacity. Here, we show that CM, which is characterized by a very high capacity to oxidize fatty acids, displayed the lowest basal levels of UCP3 by far. Basal UCP3 levels in $\mathrm{CM}$ were approximately 13 -fold lower in comparison with the mainly glycolytic WGM, whereas UCP3 in the latter was approximately 4.5 -fold higher when compared to the oxidative SM.

Recently, Russell et al. [7] quantitatively compared UCP3 protein levels in type 1 , type $2 \mathrm{a}$ and type $2 \mathrm{~b}$ muscle fibers in human $\mathrm{m}$. vastus lateralis using immunofluorescence. In the present study, we confirm these results and earlier qualitative results from our group [15] and others [14], showing that oxidative muscles express the lowest levels of UCP3 protein com- pared to glycolytic muscle types that express high levels of UCP3. These data support our hypothesis that UCP3 facilitates export of non-metabolizable fatty acids.

As reported previously [2-4], we confirm at the protein level that high-fat feeding upregulates UCP3, compared to low-fat feeding. This upregulation was most pronounced in CM (11.5fold) and only 2-fold in glycolytic muscle. According to our hypothesis, the balance between fatty acid delivery to the muscle cell and the oxidative capacity of this cell, drives UCP3 expression. On the one hand, it could thus be reasoned that upon high-fat feeding, the greatest changes in UCP3 protein would be expected in muscles with a low fatty acid oxidation capacity, like WGM. On the other hand, it should be noted that basal UCP3 levels in CM and SM are very low. If basal UCP3 levels are taken into account, UCP3 protein levels upon HF feeding are still 2.1-fold higher in WGM compared to SM and 2.3-fold higher than CM.

Upregulation of UCP3 upon high-fat feeding is consistent with the proposed physiological function of $\mathrm{UCP} 3$, since in this condition non-metabolizable fatty acids are more likely to reach the matrix. However, in contrast to LCFA, which need to be activated to long chain fatty acyl-CoA by the ACS in 
the cytosol, all MCFA that enter the mitochondrial matrix can be oxidized. Therefore, accumulation of fatty acid anions inside the mitochondrial matrix is unlikely to occur upon HF MCT feeding and the need for UCP3 is thus diminished compared to HF LCT feeding. Here we confirm the absence of an upregulation of UCP3 upon the HF MCT diet [19] in skeletal and CMs with different fat oxidative capacity, further supporting our hypothesis that UCP3 acts as an exporter of non-metabolizable fatty acid anions.

Very recently, it was suggested that UCP3 does not export fatty acid anions but rather fatty acid peroxide anions [25]. Based on our metabolic data we cannot conclude whether UCP3 transports fatty acid anions or fatty acid peroxide anions, but both hypotheses state that UCP3 has an important role in protecting mitochondria against fatty-acid-induced mitochondrial damage.

An alternative explanation for the present results could be differential effects of MCT vs. LCT on PPAR activation, as the promoter of the UCP3 gene contains a PPAR responsive element [21]. Although plasma non-esterified fatty acids were similar on MCT and LCT diets, it is also known that especially LCFA are potent PPAR ligands while fatty acids of medium chain length are poor PPAR activators [22,23]. Therefore, the observed upregulation of UCP3 upon HF LCT but not on HF MCT feeding could be general PPARmediated effects.

However, we show that UCP3 mRNA levels in CM and skeletal muscle displayed the same expression pattern observed on the protein level, following the different dietary interventions. In contrast, neither ACS nor LCAD showed differences in mRNA levels in reaction to the dietary interventions, in any of the muscle types studied (Fig. 3). These results indicate that HF LCT and HF MCT feeding did not induce different PPAR responses. Collectively, these findings suggest that the upregulation of UCP3 upon high-fat LCT feeding is very specific, and suggest that the observed upregulation is of physiological and functional importance.

An early proposed physiological function of UCP3 was the regulation of energy expenditure. In this context, it is important to note that high-fat LCT feeding induced a more prominent increase in body mass compared to MCT feeding, even though net energy intake (gross energy intake minus energy lost in feces) was similar. This observation indicates a possible thermogenic effect of MCT consumption, although we cannot exclude the possibility that activity-induced energy expenditure was different among the groups. Earlier animal studies revealed lower weight gain and smaller adipose tissue depots upon MCT feeding compared to a LCT diet, suggesting a lower storage efficiency of MCTs [26-29]. Recently, St-Onge et al. [30] also reported decreased adipose tissue storage upon a diet rich in MCTs in overweight human males. Several animal [31-33] and human [30,34-37] studies also reported a thermogenic effect of MCT ingestion. In addition, MCTs are rapidly absorbed in the intestine and preferentially oxidized. The increased intestinal uptake was confirmed by our results since MCT fed animals showed a significantly lower fecal energy loss than LCT fed animals. Together these data suggest a lower storage efficiency and thermogenic effect of MCTs. Importantly, this MCT-induced thermogenesis occurs while a significant upregulation of UCP3 is lacking. If the primary role of $\mathrm{UCP} 3$ were to regulate energy expenditure by increasing thermogenesis one would expect a substantial increase in the (thermogenic) HF MCT condition rather than in the HF LCT condition. Again this finding underscores our notion that the primary role of UCP3 is not in the thermogenic response. Accordingly, the mechanism behind the thermogenic effect of MCTs does not seem to be mediated by UCP3.

In summary, we found that UCP3 levels in CM are, as expected, very low when compared to glycolytic skeletal muscle. In addition, UCP3 protein levels were upregulated in WGM, SM and CM after 2 weeks of high-fat, LCT feeding. High-fat, MCT feeding did not affect UCP3 protein levels in any of these muscles. Since plasma non-esterified fatty acids and the expression of ACS an LCAD, two PPAR responsive genes, were similar after HF LCT and HF MCT feeding, the effects on UCP3 levels seems to be very specific. Taken together, these data support our hypothesis that UCP3 acts as a fatty acid anion exporter to prevent mitochondrial accumulation of non-metabolizable fatty acids.

Acknowledgements: The research of P.S. has been made possible by a fellowship of the Royal Netherlands Academy of Arts and Sciences. J.H. was supported by a grant from the Netherlands Organization for Scientific Research (NWO), and M.v.B. is an Established Investigator of the Netherlands Heart Foundation (Grant 1998T015).

\section{References}

[1] Millet, L., Vidal, H., Andreelli, F., Larrouy, D., Riou, J.P., Ricquier, D., Laville, M. and Langin, D. (1997) J. Clin. Invest. 100, 2665-2670.

[2] Hesselink, M.K. et al. (2003) J. Clin. Invest. 111, 479-486.

[3] Matsuda, J. et al. (1997) FEBS Lett. 418, 200-204.

[4] Schrauwen, P., Hoppeler, H., Billeter, R., Bakker, A.H. and Pendergast, D.R. (2001) Int. J. Obes. Relat. Metab. Disord. 25, 449-456.

[5] Tsuboyama-Kasaoka, N., Tsunoda, N., Maruyama, K., Takahashi, M., Kim, H., Ikemoto, S. and Ezaki, O. (1998) Biochem. Biophys. Res. Commun. 247, 498-503.

[6] Schrauwen, P., Saris, W.H. and Hesselink, M.K. (2001) FASEB J. 15, 2497-2502.

[7] Russell, P. et al. (2003) Pflug. Arch. 445, 563-569.

[8] Vidal-Puig, A., Rosenbaum, M., Considine, R.C., Leibel, R.L., Dohm, G.L. and Lowell, B.B. (1999) Obes. Res. 7, 133-140.

[9] Schrauwen, P., Schaart, G., Saris, W.H., Slieker, L.J., Glatz, J.F., Vidal, H. and Blaak, E.E. (2000) Diabetologia 43, 14081416.

[10] Jezek, P., Orosz, D.E., Modriansky, M. and Garlid, K.D. (1994) J. Biol. Chem. 269, 26184-26190.

[11] Jezek, P., Engstova, H., Zackova, M., Vercesi, A.E., Costa, A.D., Arruda, P. and Garlid, K.D. (1998) Biochim. Biophys. Acta 1365, 319-327.

[12] Skulachev, V.P. (1999) J. Bioenerg. Biomembr. 31, 431-445.

[13] Himms-Hagen, J. and Harper, M.E. (2001) Exp. Biol. Med. (Maywood) 226, 78-84.

[14] Boss, O., Samec, S., Paoloni-Giacobino, A., Rossier, C., Dulloo, A., Seydoux, J., Muzzin, P. and Giacobino, J.P. (1997) FEBS Lett. 408, 39-42.

[15] Hesselink, M.K. et al. (2001) FASEB J. 15, 1071-1073.

[16] Skarka, L., Bardova, K., Brauner, P., Flachs, P., Jarkovska, D., Kopecky, J. and Ostadal, B. (2003) J. Mol. Cell Cardiol. 35, 321330 .

[17] Vettor, R. et al. (2002) Int. J. Obes. Relat. Metab. Disord. 26, 838-847.

[18] Chou, C.J., Cha, M.C., Jung, D.W., Boozer, C.N., Hashim, S.A. and Pi-Sunyer, F.X. (2001) Obes. Res. 9, 313-319.

[19] Schrauwen, P. et al. (2003) FASEB J., (in press).

[20] Jackson, S., Schaefer, J., Middleton, B. and Turnbull, D.M. (1995) Biochem. Biophys. Res. Commun. 214, 247-253.

[21] Solanes, G., Pedraza, N., Iglesias, R., Giralt, M. and Villarroya, F. (2003) Mol. Endocrinol., in press. 
[22] Desvergne, B. and Wahli, W. (1999) Endocr. Rev. 20, 649-688.

[23] Gilde, A.J. and Van Bilsen, M. (2003) Acta Physiol. Scand. 178, 425-434.

[24] Van der Lee, K.A. et al. (2001) J. Lipid Res. 42, 1752-1758.

[25] Goglia, F. and Skulachev, V.P. (2003) FASEB J. 17, 1585-1591.

[26] Hashim, S.A. and Tantibhedyangkul, P. (1987) Lipids 22, 429434.

[27] Han, J., Hamilton, J.A., Kirkland, J.L., Corkey, B.E. and Guo, W. (2003) Obes. Res. 11, 734-744.

[28] Geliebter, A., Torbay, N., Bracco, E.F., Hashim, S.A. and Van Itallie, T.B. (1983) Am. J. Clin. Nutr. 37, 1-4.

[29] Crozier, G., Bois-Joyeux, B., Chanez, M., Girard, J. and Peret, J. (1987) Metabolism 36, 807-814.

[30] St-Onge, M.P., Ross, R., Parsons, W.D. and Jones, P.J. (2003) Obes. Res. 11, 395-402.
[31] Rothwell, N.J. and Stock, M.J. (1987) Metabolism 36, 128-130.

[32] Baba, N., Bracco, E.F. and Hashim, S.A. (1982) Am. J. Clin. Nutr. 35, 678-682.

[33] Lasekan, J.B., Rivera, J., Hirvonen, M.D., Keesey, R.E. and Ney, D.M. (1992) J. Nutr. 122, 1483-1492.

[34] Dulloo, A.G., Fathi, M., Mensi, N. and Girardier, L. (1996) Eur. J. Clin. Nutr. 50, 152-158.

[35] Scalfi, L., Coltorti, A. and Contaldo, F. (1991) Am. J. Clin. Nutr. 53, 1130-1133.

[36] St-Onge, M.P., Bourque, C., Jones, P.J., Ross, R. and Parsons, W.E. (2003) Int. J. Obes. Relat. Metab. Disord. 27, 95-102.

[37] Seaton, T.B., Welle, S.L., Warenko, M.K. and Campbell, R.G. (1986) Am. J. Clin. Nutr. 44, 630-634. 